\title{
Spermidine Suppressed the Inhibitory Effects of Polyamines Inhibitors Combination in Maize (Zea mays L.) Seedlings under Chilling Stress
}

\author{
Canhong Gao ${ }^{1,2}$, Mohamed S. Sheteiwy ${ }^{3}$, Chen Lin ${ }^{2}$, Yajing Guan ${ }^{2, *} \mathbb{C}$, Zaid Ulhassan 4 (@) and Jin Hu ${ }^{2, *}$ \\ 1 College of Agriculture, Anhui Agricultural University, Hefei 230036, China; gaocanhong@163.com \\ 2 Seed Science Center, College of Agriculture and Biotechnology, Zhejiang University, Hangzhou 310058, China; \\ lincheng837243270@163.com \\ 3 Department of Agronomy, Faculty of Agriculture, Mansoura University, Mansoura 35516, Egypt; \\ salahco_2010@yahoo.com \\ 4 Laboratory of Spectroscopy Sensing, Institute of Crop Science, Ministry of Agriculture and Rural Affairs, \\ Zhejiang University, Hangzhou 310058, China; zaidulhassan007@yahoo.com \\ * Correspondence: vcguan@zju.edu.cn (Y.G.); jhu@zju.edu.cn (J.H.)
}

Citation: Gao, C.; Sheteiwy, M.S.; Lin, C.; Guan, Y.; Ulhassan, Z.; Hu, J. Spermidine Suppressed the Inhibitory Effects of Polyamines Inhibitors Combination in Maize (Zea mays L.) Seedlings under Chilling Stress. Plants 2021, 10, 2421. https:// doi.org/10.3390/plants10112421

Academic Editor: Magda Pál

Received: 11 October 2021

Accepted: 4 November 2021

Published: 10 November 2021

Publisher's Note: MDPI stays neutral with regard to jurisdictional claims in published maps and institutional affiliations.

Copyright: (C) 2021 by the authors Licensee MDPI, Basel, Switzerland. This article is an open access article distributed under the terms and conditions of the Creative Commons Attribution (CC BY) license (https:// creativecommons.org/licenses/by/ $4.0 /)$.

\begin{abstract}
Chilling stress greatly inhibited the seed germination, plant growth, development and productivity in this study. The current research aimed to study the effects of different polyamine (PA) inhibitor combinations (Co), e.g., D-arginine (D-Arg), difluoromethylormithine (DFMO), aminoguanidine (Ag) and methylglyoxyl-bis-(guanyhydrazone) (MGBG) at different doses, i.e., $10 \mu \mathrm{M} \mathrm{Co}$, $100 \mu \mathrm{M}$ Co, $500 \mu \mathrm{M}$ Co, $1000 \mu \mathrm{M}$ Co and $1000 \mu \mathrm{M}$ Co +1 mM Spd (Spermidine) in two inbred lines of maize (Zea mays L.), i.e., Mo17 and Huang C, a sensitive and tolerant chilling stress, respectively. The combination treatments of PA inhibitors reduced the biosynthesis of putrescine (Put) in the tissues of both studied inbred lines. Application with $500 \mu \mathrm{M}$ Co and $1000 \mu \mathrm{M}$ Co did not result in a significant difference in Put concentrations, except in the coleoptile of Mo17. However, combining Spd to $1000 \mu \mathrm{M}$ of PA inhibitors enhanced the Put, Spd, spermine (Spm) and total PAs in the roots, coleoptile and mesocotyls. Put and total PAs were increased by $39.7 \%$ and $30.54 \%$, respectively, when Spd $+1000 \mu \mathrm{M}$ Co were applied relative to their controls. Chilling stress and PA inhibitors treatments affected both inbred lines and resulted in differences in the PA contents. Results showed that enzymes involved in the biosynthesis of PAs (ornithine decarboxylase as ODC and S-adenosylmethionine decarboxylase as SAMDC) were significantly downregulated by $1000 \mu \mathrm{M}$ Co in the tissues of both inbred lines. In contrast, the activity of PAO, a Pas degradation enzyme, was significantly improved by $1000 \mu \mathrm{M}$ Co under chilling stress. However, Spd $+1000 \mu \mathrm{M}$ Co significantly improved the activities of ODC and SAMDC and their transcript levels (ODC and SAMDC2). While it significantly downregulated the PAO activity and their relative genes (PAO1, PAO2 and PAO3) under chilling stress. Overall, this study elucidates the specific roles of Spd on the pathway of PA inhibitors and PA biosynthesis metabolism in maize seed development in response to chilling stress. Moreover, the Huang C inbred line was more tolerant than Mo17, which was reflected by higher activities of PA biosynthesis-related enzymes and lower activities of PAs' degradative-related enzymes in Huang C.
\end{abstract}

Keywords: polyamines; maize; chilling stress; spermidine; gene expression

\section{Introduction}

Agricultural crops are confronted by a number of abiotic stress factors that limit their productivity [1-5]. Among abiotic stresses, chilling stress is one of the most severe stresses, which substantially inhibits the seed germination and seedlings development [6]. Lowtemperature stress could reduce the growth and development of maize seedlings under field conditions. Maize has been reported to be sensitive to low temperature [7,8], especially at early growth stages, which results in the inhibition of seed germination and vegetative 
growth [9-11]. Previous studies reported that many physiological and metabolic processes of plants are repressed by chilling stress [12]. The tolerant level of maize plants depends on the hybrid type at both the chilling and recovery periods [7,13-16]. The exposure of chilling stress impairs numerous physiological and molecular functions of plants [12]. For instance, low-temperature stress can reduce the crop productivity through various actions such as reduction in plant growth rates [14], water uptake disturbance [15], photosynthesis efficiency [16], changes in membrane properties [17], extra production of reactive oxygen species (ROS) [18] and enzymatic and non-enzymatic antioxidants [19].

Increasing polyamine (PA) concentrations in plants during chilling stress could protect plant cells $[20,21]$. PAs have reported to be involved in several physiological and developmental processes in plants, such as survival of plant embryos and translation [22], cell proliferation, modulated gene expression and membrane stabilization [23,24]. Their substrates are present extracellularly and play a vital role in regulating the specific destined physiological processes such as lignification, oxidative burst, suberization and defense mechanisms [25]. The interaction of PAs (Spd and Spm) with plants and their mechanisms underpin the tolerance to environmental stresses and have been investigated in cereals and pulses at different aspects [26]. Polyamines (particularly Put, Spd and Spm) are involved in several physiological, metabolic and molecular mechanisms to regulate the plant growth and development under the abiotic stresses including chilling stress [27]. As such, PA catabolism pathway improved DAO and PAO activities, stimulating the generation of $\mathrm{H}_{2} \mathrm{O}_{2}$ molecules, which act as signaling molecules to improve antioxidant systems and alleviate oxidative damages [28]. Previous reports showed that PAs may alleviate chilling stress effects on the photosynthetic system due to their antioxidant properties [29] or their effect on the thylakoid membrane [30]. The key physiological and biochemical mechanism is that PAs may enhance plants adaptations to abiotic stress tolerance via their significant roles in osmotic regulation, inhibition in lipids peroxidation, stability and integrity of cellular membranes, scavenging oxidative stress, improvement in antioxidant enzymes and interaction with proteins and phytohormones biosynthesis [31]. Recently, several studies reported that seed priming with Spd substantially protected the cellular structures and alleviated the abiotic stress factors including salinity [32], heat [33] and chilling [34]. PAs can play important roles in improving the growth of several crop species under stress condition [35]. A previous study showed that Spd treatments have improved the seed vigor and growth of sweet corn as reflected by higher germination percentage, shoot height and dry weights of shoots and roots in comparison to their relative controls [36]. It had been reported that exogenous Spd at $0.01-1.0 \mathrm{mM}$ concentrations improved alpha-amylase activity and seed germination in maize [37]. In addition, seed soaking with Spd was found to enhance the seed vigor and reduce the detrimental effects of chilling stress on the rice seeds, and thus enhance the chilling tolerance potential of rice seedlings [38,39].

PAs have modulated several biological functions such as cell division, differentiation and senescence, which enabled plants to cope with abiotic stress [40,41]. Additionally, they can stimulate cellular defense against oxidative damages through scavenging the free radicals induced by lipid peroxidation [42,43]. PAs play major roles in nitrogenous compounds metabolism in plants under normal as well as environmental conditions [44]. A recent study showed that the application of PAs to plants enhanced the shoot induction, root elongation and transformation efficiency in soybean [45]. A previous report stated that plants treated with exogenous Spd significantly increased endogenous Spd content, gibberellins and ethylene contents, while resulting in a reduction of ABA concentration in maize grain during seed development [37]. Moreover, changes in the transcription level of $A D C$ genes and their activities were observed in Brassica juncea [46] and Malus sylvestris [47-50] under chilling stress. In chickpea genotypes, the activities of PA metabolism-associated diamine oxidase (DAO) and polyamine oxidase (PAO) enzymes as well as PA biosynthesis genes, such as arginine decarboxylase $(A D C)$, spermidine synthase (SPDS1 and SPDS2) and spermine synthase (SPMS), were upregulated under cold stress. Additionally, higher accumulation of Spd, Spm and Put contents, photosynthetic pigments and an elevated antioxidant de- 
fense system were more noticed in tolerant than sensitive genotypes under cold stress [28]. Similarly, the relative expression of the other PA-related genes such SAMDC were also affected in the saline condition in rice [51], soybean [52], wheat [53], Arabidopsis [54], apple [55] and maize [56]. PAs are oxidatively activated by the interaction of amine oxidases such as copper DAO and flavoprotein PAO. DAO reacts with Put and produces pyrroline, hydrogen peroxide and ammonia, while PAO reacts with Spd and Spm and produces pyrroline and 1,5-diabicyclononane, respectively, along with diaminopropane (Dap) and hydrogen peroxide. Both DAO and PAO enzymes are involved in PA biosynthesis, and their byproducts are involved in important physiological processes of plants under abiotic stress [57]. A previous study showed that cold stress decreased both transcripts in root tissues, while the accumulation of the ZmMET1 transcript in the shoot mesocotyl was not affected by cold stress [58].

This study investigated the physiological changes in maize tissues by Spd under cold stress. Previous studies have only focus on the effect of PAs on alleviation of cold tolerance. In the present study, we focused on these effects beside their effects on the PA inhibitors and its signaling in the different tissues of maize. Hence, it is of great importance to analyze the content of PAs, enzymes involved in PA biosynthesis and their transcription levels under chilling stress for further understanding of the Spd-induced mechanism for enhancements to chilling tolerance and to provide insights for further analysis. Moreover, the genetic manipulation of the genes involved in PA biosynthetic pathways in different maize tissues may further elucidate the role of PA in plant developments under chilling stress. The present study hypothesized that the conversion of Spd to Put in the Spd-treated seedling in the presence of PA inhibitors and chilling stress. This statement supports the potential resources for the conversion of Spd to Put and can be used a physiological signal in maize under chilling stress. For this purpose, both sensitive and tolerant lines of maize to chilling stress were used as experimental materials under low temperature and sectioned into three tissues (root, mesocotyl and coleoptile). D-arginine (D-Arg), a competitive inhibitor of $\mathrm{ADC}$ and DFMO (difluoromethylornithine) and irreversible inhibitor of ODC, was used to inhibit the biosynthesis of Put. Aminoguanidine (Ag) was used to inhibit the degradation of Put. Methylglyoxyl-bis- (guanyhydrazone) (MGBG), a powerful inhibitor of SAMDC, was used to inhibit biosynthesis of Spd and Spm from Put [59]. The combinations of four PA inhibitors with different concentrations of exogenous Spd were used to investigate the potential roles of Spd in inhibiting the PA inhibitors' effects in the root, mesocotyl and coleoptile and in the improvement in maize tolerance under chilling stress conditions.

\section{Materials and Methods}

\subsection{Plant Materials and Growth Condition}

Two inbred lines of maize cvs. Hung C (chilling tolerant) and Mo17 (chilling sensitivity) [60] were obtained from the Seed Center, College of Agriculture and Biotechnology, Hangzhou. All the seeds were stored at $4{ }^{\circ} \mathrm{C}$ before the seed germination test. The seeds were then sterilized for $5 \mathrm{~min}$ [61], then distilled water was used for seed washing (thrice) before the germination test. Thereafter, the sterilized seeds were germinated in darkness at $25^{\circ} \mathrm{C}$ for 3 days in paper germination towels moistened with water. The normal seedlings with consistent growth were selected and incubated in Hoagland solution containing PA inhibitor combinations for 1 day at $25^{\circ} \mathrm{C}$, and then grown for 3 days at a low temperature $\left(5^{\circ} \mathrm{C}\right)$. Four PA inhibitors with different inhibitory functions were used together as a combination at different concentrations to check differential responses of treatments/inhibitors in both maize inbred lines. After that, the seedlings were transferred to constant temperature of $25{ }^{\circ} \mathrm{C}$ for 3 days as recovery period growth. For all of the growth period in the Hoagland solution, seedlings had a diurnal cycle of $12 \mathrm{~h}$ of light with luminous flux of $250 \mu \mathrm{mol} \mathrm{m} \mathrm{m}^{-2} \mathrm{~s}^{-1}$ and $12 \mathrm{~h}$ of darkness. Three replicates for each treatment and 50 seeds for each replicate were used in this study. Four polyamines' inhibitors were used, e.g., D-arginine (D-Arg), difluoromethylormithine (DFMO) (an inhibitor for putrescine biosynthesis), aminoguanidine (Ag, an inhibitor for putrescine degradation) and 
methylglyoxyl-bis- (guanyhydrazone) (MGBG) (an inhibitor for spermidine, spermine and putrescine biosynthesis). The different concentrations of these PA inhibitors' combinations were subjected to a preliminary screening test. The purpose is to use a combination of PA inhibitors to inhibit the production of Put, to the level that the content of Put does not decrease. After which the exogenous Spd was used to check the changes in Put content and whether Spd converts into Put. Therefore, in order to study whether Spd can convert into Put, a $1000 \mu \mathrm{M}$ combination was used as a control, then $1 \mathrm{mM}$ Spd was applied on this basis (1 mM Spd + $1000 \mu \mathrm{M}$ combination). The polyamine inhibitor combinations (Co.) in Hoagland solutions were used as follows:

(1) $10 \mu \mathrm{M}$ Co. $(10 \mu \mathrm{M}$ D-Arg, $10 \mu \mathrm{M}$ DFMO, $10 \mu \mathrm{M}$ MGBG and $100 \mu \mathrm{M} \mathrm{Ag})$;

(2) $100 \mu \mathrm{M}$ Co. (100 $\mu \mathrm{M}$ D-Arg, $100 \mu \mathrm{M}$ DFMO, $100 \mu \mathrm{M}$ MGBG and $1000 \mu \mathrm{M} \mathrm{Ag})$;

(3) $500 \mu \mathrm{M}$ Co. (500 $\mu \mathrm{M}$ D-Arg, $200 \mu \mathrm{M}$ DFMO, $500 \mu \mathrm{M}$ MGBG and $5 \mathrm{mM} \mathrm{Ag}$ );

(4) $1000 \mu \mathrm{M}$ Co. (1000 $\mu \mathrm{M}$ D-Arg, $200 \mu \mathrm{M}$ DFMO, $1000 \mu \mathrm{M}$ MGBG and $10 \mathrm{mM}$ Ag);

(5) Spd $+1000 \mu \mathrm{M}$ Co. (1 mM Spd + $1000 \mu \mathrm{M}$ D-Arg, $200 \mu \mathrm{M}$ DFMO, $1000 \mu \mathrm{M}$ MGBG, $10 \mathrm{mM} \mathrm{Ag}$ ) and the control of seedlings were without any treatment of polyamine inhibitors.

\subsection{Polyamine Assay}

PA concentrations in the roots, mesocotyls and coleoptile tissues of the maize seedlings were immediately measured after grown at low temperature $\left(5^{\circ} \mathrm{C}\right)$. Three replicates of 25 normal seedlings for each treatment were used for polyamines assay. Polyamine contents were estimated according to the method of [60]. Briefly, fresh samples $(0.1 \mathrm{~g})$ were homogenized with $1 \mathrm{~mL}$ of $5 \%(w / v)$ cold $\mathrm{HClO}_{4}$, kept for $1 \mathrm{~h}$ in ice and centrifuged for $30 \mathrm{~min}$ at $4{ }^{\circ} \mathrm{C}$ at $23,000 \times g$. Then, the supernatant was stored at $-70{ }^{\circ} \mathrm{C}$ for PA measurements. The PA standard samples for Put, Spd and Spm were prepared at different contents for the development of standard curves. Then the samples were subjected to HPLC, with $3.9 \times 150 \mathrm{~mm}, 4 \mu \mathrm{m}$ particle size reverse-phase (C18) column and a Waters 2487 dual $\lambda$ absorbance detector.

\subsection{Polyamine Biosynthesis Enzymes under Chilling Stress}

The PA biosynthesis-related enzymes were estimated using the previous method [39]. For this purpose, $0.5 \mathrm{~g}$ for each the different tissues of maize (roots, mesocotyls and coleoptiles) from only the control, and $1000 \mu \mathrm{M} \mathrm{Co}$. and Spd + $1000 \mu \mathrm{M}$ Co.-treated plants were ground and homogenized with $3 \mathrm{~mL}$ of extraction buffer ( $\mathrm{pH} 8.0)$ containing $25 \mathrm{mM}$ potassium phosphate, $50 \mu \mathrm{M}$ EDTA, 100 -M phenylmethylsulphonyl fluoride, $1 \mathrm{mM} 2$ 2mercaptoethanol and $25 \mathrm{mM}$ ascorbic acid. The activities of ADC, ODC and SAMDC were determined according to the method of Lee et al. [62]. The reaction buffers for the ADC, ODC and SAMDC assays were $0.1 \mathrm{~mL}$ of $200 \mathrm{mM}$ Tris- $\mathrm{HCl}(\mathrm{pH} 8.5)$ buffer, $0.1 \mathrm{~mL}$ of $200 \mathrm{mM}$ Tris- $\mathrm{HCl}$ ( $\mathrm{pH} 8.0$ ) buffer and $0.1 \mathrm{~mL}$ of $200 \mathrm{mM}$ potassium-phosphate ( $\mathrm{pH}$ 7.5) buffer, respectively. Then, the activities of ADC, ODC and SAMDC enzymes were determined by measuring the $\mathrm{CO}_{2}$ evolution. Spd synthase activity was estimated using the reported method of Kasukabe et al. [35].

\subsection{Polyamines' Degradative Enzymes under Chilling Stress}

For polyamine oxidase (PAO) activity determination, $0.5 \mathrm{~g}$ of the tissues from only the control and $1000 \mu \mathrm{M}$ Co. and Spd $+1000 \mu \mathrm{M}$ Co.-treated plants were homogenized in $0.5 \mathrm{~mL}$ of $0.2 \mathrm{M}$ phosphate buffer ( $\mathrm{pH} 6.5$ ) and centrifuged at $8000 \times g$ for $15 \mathrm{~min}$ at $4{ }^{\circ} \mathrm{C}$ [39]. The contents of $\mathrm{H}_{2} \mathrm{O}_{2}$ in grains were measured and expressed as $\mathrm{mol} \mathrm{g}^{-1} \mathrm{DW}$ [63].

\subsection{Transcript Levels of PA Biosynthesis Genes}

In order to analyze the transcription levels of PA biosynthesis genes, frozen tissues (200 mg) from only the control and from $1000 \mu \mathrm{M}$ Co. and Spd + $1000 \mu \mathrm{M}$ Co.-treated plants were ground thoroughly. Total RNA was extracted from the control and different treated seedlings by using RNA isolation. The concentration of the RNA was tested by 
NanoDrop [64]. cDNA was synthesized using Primer Script RT Reagent Kit from $1 \mu \mathrm{g}$ of total RNA in a $20 \mu \mathrm{L}$ reaction and diluted 4 -fold with water. The primers used in real-time PCR (RT-PCR) are presented in Table 1. ACT1 was used as an endogenous control gene to normalize expression of the other genes. The PCR program was as follows: $30 \mathrm{~s}$ at $95^{\circ} \mathrm{C}$, followed by 40 cycles of $10 \mathrm{~s}$ at $95^{\circ} \mathrm{C}$ and $30 \mathrm{~s}$ at $60^{\circ} \mathrm{C}$.

Table 1. Real-time PCR primers for genes expressions detection.

\begin{tabular}{|c|c|c|c|}
\hline Locus & Primer Name & Primer Orientation & Sequence $\left(5^{\prime}-3^{\prime}\right)$ \\
\hline \multirow{2}{*}{ NC_008332.1 } & 18s rRNA & Forward & ACATGCGCCTAAGGAGAAATAG \\
\hline & 18s rRNA & Reverse & ACCTCCATGCTCACTGGTACTT \\
\hline \multirow{2}{*}{ NM_001323076 } & ZmADC1 & Forward & GCTACGGCTCAAGGTACCAG \\
\hline & ZmADC1 & Reverse & CCGAACTCCACAATGTCСТC \\
\hline \multirow{2}{*}{ NM_001138726 } & ZmADC2 & Forward & GGAGCCACTCATGACCAAAG \\
\hline & $\mathrm{ZmADC2}$ & Reverse & CAGGGACCTTGTATTCGTTGA \\
\hline \multirow{2}{*}{ NM_001148682 } & $\mathrm{ZmODC}$ & Forward & GCGCCTACTCCACAGGTTC \\
\hline & $\mathrm{ZmODC}$ & Reverse & CGTAGATCTTAATCTCCGACGTG \\
\hline \multirow{2}{*}{ NM_001155838 } & ZmSPDS & Forward & TGTTCAATTCCATССССТАAA \\
\hline & ZmSPDS-R & Reverse & TCCACTGAACTGTGTCTGGAA \\
\hline \multirow{2}{*}{ NM_001112243 } & ZmSAMDC2 & Forward & TGTGGCTACTCCATGAATGC \\
\hline & ZmSAMDC2 & Reverse & CGTAACTGGCGTAGCTGAAA \\
\hline \multirow{2}{*}{ NM_001111636 } & ZmPAO1 & Forward & CCAGCAGCAGGAGAGGTTAC \\
\hline & $\mathrm{ZmPAO} 1$ & Reverse & GCGTCAGGGTACTGCTTCTC \\
\hline \multirow{2}{*}{ NM_001329439 } & $\mathrm{ZmPAO} 2$ & Forward & CACACACACCATCCGCTATT \\
\hline & $\mathrm{ZmPAO} 2$ & Reverse & CATCAGCAGCAGCAAGACC \\
\hline \multirow{2}{*}{ XM_008652490 } & $\mathrm{ZmPAO3}$ & Forward & AAAGCCACACACACCATCTG \\
\hline & $\mathrm{ZmPAO} 3$ & Reverse & CAGCAGCAGCAAGACCTGTA \\
\hline
\end{tabular}

\subsection{Statistical Analysis}

Treatments were arranged in completely randomize design (CRD) using a factorial experiment. Before ANOVA, the data of the percentages were transformed according to $\mathrm{y}=\arcsin [\operatorname{sqrt}(\mathrm{x} / 100)]$. All the results are the mean of three replicates \pm standard deviation (SD) and all the data were subjected to an analysis of variance (ANOVA). When a significant $(p<0.05)$ F ratio occurred for treatment effects, a least significant difference (LSD) was calculated.

\section{Results}

\subsection{Polyamine Concentration in Roots of Maize Seedlings}

The mean data regarding the Put, Spd, Spm and total PAs in the root of both studied inbred lines as affected by the PA inhibitors and chilling stress are presented in Table 2. The contents of Put, Spd, Spm and total PAs were decreased in the seedlings exposed to chilling and PA inhibitors (Table 2). Under control conditions, Put, Spd, Spm and total PA contents were improved as compared to the PA inhibitor-treated seedlings. The lowest values of Put, Spd, Spm and total PAs were recorded at the exposure of $500 \mu \mathrm{M}$ of PA inhibitor combinations. However, Spd combined with $1000 \mu \mathrm{M}$ significantly improved the Put, Spd, Spm and total polyamines under chilling stress for both studied inbred lines. Moreover, the application with $10 \mu \mathrm{M}$ was found to have the lowest negative effects on the Put, Spd, Spm and total PA contents in the maize roots as compared to 100, 500 and $1000 \mu \mathrm{M}$ PA inhibitor treatments. The contents of Put and Spd in roots were higher in the Huang C inbred line under all PA inhibitor combinations and chilling stress, while the Spm contents were higher in Mo17 inbred line under the same treatments (Table 2). The concentrations of Spd in the seedlings treated with Spd + 1mM combinations were found to be lower than those observed in control seedlings. Moreover, Spd concentrations in the roots of Huang C were significantly decreased as the combination treatments were increased from $10 \mu \mathrm{M}$ to $1000 \mu \mathrm{M}$. On the other hand, Spm concentrations in the roots of Mo17 were significantly decreased as the combination treatments were increased from $10 \mu \mathrm{M}$ to $1000 \mu \mathrm{M}$, and the 
four combination treatments showed a significant decrease in Spm concentration relative to their controls (Table 2). The alterations' trends in the values of total PA concentrations in the roots of Mo17 were similar to those of Put concentrations. It could be concluded that the Put and total polyamines were increased by $39.68 \%$ and $30.54 \%$, respectively, by combining the Spd with $1000 \mu \mathrm{M}$ relative to their controls.

Table 2. Effect of polyamine inhibitor combination treatments on polyamine concentrations of the root ( $\mathrm{n} \mathrm{mol} / \mathrm{g} \mathrm{FW}$ ) under low-temperature stress.

\begin{tabular}{|c|c|c|c|c|c|c|c|c|}
\hline \multirow{2}{*}{ Treatment } & \multicolumn{2}{|c|}{ Put } & \multicolumn{2}{|c|}{ Spd } & \multicolumn{2}{|c|}{ Spm } & \multicolumn{2}{|c|}{ Total Polyamine } \\
\hline & Mo17 & Huang C & Mo17 & Huang C & Mo17 & Huang C & Mo17 & Huang C \\
\hline $0(\mathrm{CK})$ & $639.5 \mathrm{~b}$ & $673.3 \mathrm{~b}$ & $178.7 \mathrm{a}$ & $302.9 \mathrm{a}$ & $23.6 \mathrm{a}$ & $13.6 \mathrm{a}$ & $841.8 \mathrm{~b}$ & $989.8 \mathrm{~b}$ \\
\hline $10 \mu \mathrm{M}$ Co. & 551.7 c & $559.9 c$ & $100.9 c$ & $289.1 \mathrm{c}$ & $17.2 \mathrm{~b}$ & $9.8 \mathrm{~b}$ & $669.8 \mathrm{c}$ & $858.7 \mathrm{C}$ \\
\hline 100 нM Co. & $311.6 \mathrm{~d}$ & $424.8 \mathrm{~d}$ & $85.4 \mathrm{c}$ & $282.0 \mathrm{c}$ & $11.8 \mathrm{c}$ & $1.4 \mathrm{~d}$ & $408.8 \mathrm{~d}$ & $708.1 \mathrm{~d}$ \\
\hline $500 \mu \mathrm{M}$ Co. & $239.6 \mathrm{e}$ & $358.3 \mathrm{e}$ & $92.5 \mathrm{c}$ & $194.7 \mathrm{~d}$ & $4.4 \mathrm{~d}$ & $0.0 \mathrm{e}$ & $336.4 \mathrm{e}$ & $553.0 \mathrm{e}$ \\
\hline $1000 \mu \mathrm{M}$ Co. & $243.0 \mathrm{e}$ & $356.4 \mathrm{e}$ & $94.0 \mathrm{c}$ & $155.4 \mathrm{e}$ & $0.0 \mathrm{e}$ & $0.0 \mathrm{e}$ & $337.0 \mathrm{e}$ & $511.8 \mathrm{f}$ \\
\hline Spd + 1 mM Co. & $1269.7 \mathrm{a}$ & $905.6 \mathrm{a}$ & $129.8 \mathrm{~b}$ & $312.1 \mathrm{a}$ & $13.5 \mathrm{c}$ & $6.4 \mathrm{c}$ & $1412.9 \mathrm{a}$ & $1224.1 \mathrm{a}$ \\
\hline
\end{tabular}

Different letters following the data within each column mean significant difference at $p \leq 0.05$.

\subsection{Polyamine Concentration in Mesocotyl of Maize Seedlings}

The application of PA inhibitor combinations during chilling stress notably decreased the Put, Spd, Spm and total PA contents in the mesocotyls of both inbred lines as relative to their controls (Table 3). The lowest values of Put (for only Mo17) and Spd (for both inbred lines) were noticed with $100 \mu \mathrm{M}$ Co.-treated seedlings. While Spm contents were found lowest with $1000 \mu \mathrm{M}$ Co.-treated seedlings. The combination of Spd with $1000 \mu \mathrm{M}$ Co. PA inhibitors significantly improved the Put, Spd, Spm and total PAs, except for Spd and Spm contents in the Huang $C$ inbred line, which showed lower values than those of $10 \mu \mathrm{M}$ Co. of PA inhibitors (Table 3). The contents of Put and Spm in the mesocotyls of the Mo17 inbred line were higher under chilling stress and all PA inhibitor combinations, while the contents of Spd in Huang C were relatively higher under the same conditions (Table 3). Put concentrations in the mesocotyls of Mo17 that were treated by $100 \mu \mathrm{M}$, $500 \mu \mathrm{M}$ and $1000 \mu \mathrm{M}$ combinations displayed significantly lower range of values than those treated by $10 \mu \mathrm{M}$ and Spd $+1 \mathrm{mM}$ combinations and their controls (Table 3 ). The changes of Spm concentrations in the mesocotyl of Huang C were similar to those of Spd contents. Both $500 \mu \mathrm{M}$ and $1000 \mu \mathrm{M}$ combination treatments recorded significantly lower concentrations of total PA concentrations in the mesocotyls than those of the $10 \mu \mathrm{M}$ and $100 \mu \mathrm{M}$ combination-treated seedlings. There was a notable increase in Put (only in Mo17), Spd (only in Huang C), Spm (in both inbred lines) and total PAs (in both inbred lines) in the mesocotyl upon application with $10 \mu \mathrm{M}$ as compared with other PA inhibitors (Table 3). It could be concluded that the applications of 10, 100, 500 and $1000 \mu \mathrm{M}$ of PA inhibitors resulted in the following: the decrease of Put in the mesocotyls by $35.84 \%, 42.81 \%, 47.05 \%$ and $46.73 \%$, respectively; the decrease of Spd by $46.91 \%, 60.32 \%, 63.11 \%$ and $65.01 \%$, respectively; and the decrease of Spm by $33.86 \%, 60.81 \%, 78.54 \%$ and $90.60 \%$, respectively, relative to their controls (Table 3). 
Table 3. Effect of polyamine inhibitor combination treatments on polyamine concentrations of mesocotyl ( $\mathrm{n} \mathrm{mol} / \mathrm{g}$ FW) under low-temperature stress.

\begin{tabular}{|c|c|c|c|c|c|c|c|c|}
\hline \multirow{2}{*}{ Treatment } & \multicolumn{2}{|c|}{ Put } & \multicolumn{2}{|c|}{ Spd } & \multicolumn{2}{|c|}{ Spm } & \multicolumn{2}{|c|}{ Total Polyamines } \\
\hline & Mo17 & Huang C & Mo17 & Huang C & Mo17 & Huang C & Mo17 & Huang C \\
\hline 0 (CK) & $1369.8 \mathrm{a}$ & $738.4 \mathrm{a}$ & $195.8 \mathrm{a}$ & $245.0 \mathrm{a}$ & $25.0 \mathrm{~b}$ & $31.4 \mathrm{a}$ & $1589.6 \mathrm{a}$ & $1018.6 \mathrm{a}$ \\
\hline $10 \mu \mathrm{M}$ Co. & $953.7 \mathrm{c}$ & $398.9 \mathrm{c}$ & $107.0 \mathrm{~d}$ & $127.9 \mathrm{~b}$ & $24.5 \mathrm{~b}$ & $12.8 \mathrm{~b}$ & $1085.2 \mathrm{c}$ & $539.7 \mathrm{C}$ \\
\hline $100 \mu \mathrm{M}$ Co. & $805.0 \mathrm{~d}$ & $400.4 \mathrm{c}$ & $99.5 \mathrm{e}$ & $75.4 \mathrm{~d}$ & $13.3 \mathrm{c}$ & $8.8 \mathrm{~d}$ & $917.8 \mathrm{~d}$ & $484.6 \mathrm{~d}$ \\
\hline $500 \mu \mathrm{M}$ Co. & $781.2 \mathrm{~d}$ & $335.0 \mathrm{~d}$ & $111.2 \mathrm{~cd}$ & $51.4 \mathrm{e}$ & $8.5 \mathrm{~d}$ & $3.6 \mathrm{e}$ & $900.9 \mathrm{~d}$ & $390.0 \mathrm{e}$ \\
\hline 1000 нM Co. & $790.9 \mathrm{~d}$ & $332.4 \mathrm{~d}$ & $115.1 \mathrm{c}$ & $39.1 \mathrm{f}$ & $3.2 \mathrm{e}$ & $2.10 \mathrm{f}$ & $906.0 \mathrm{~d}$ & $371.5 \mathrm{e}$ \\
\hline Spd + 1 mM Co. & $1166.0 \mathrm{~b}$ & $444.3 \mathrm{~b}$ & $161.5 \mathrm{~b}$ & $117.6 \mathrm{c}$ & $41.4 \mathrm{a}$ & $11.5 \mathrm{c}$ & $1368.9 \mathrm{~b}$ & $573.3 \mathrm{~b}$ \\
\hline
\end{tabular}

Different letters following the data within each column mean significant difference at $p \leq 0.05$.

\subsection{Polyamine Concentrations in Coleoptile of Maize Seedlings}

The PA concentrations in the coleoptiles as affected by PA inhibitors combination under the chilling stress are presented in Table 4. The results showed that Put, Spd, Spm and total PAs in both maize inbred lines were decreased in the seedlings treated with PA inhibitors as compared to their controls. Application with $1000 \mu \mathrm{M}$ PA inhibitor combinations resulted in the lowest values of Put, Spd, Spm and total PAs as compared with other PA inhibitors. However, combining Spd with $1000 \mu \mathrm{M}$ Co. significantly enhanced the Put, Spd, Spm and total PA contents (Table 4). The contents of Put and Spm in coleoptiles were notably higher in Mo17 under chilling stress and PA inhibitor combinations, while Spd contents were higher in Huang $C$ under the same conditions, except in the $500 \mu \mathrm{M}$ Co.-treated Mo17 inbred line (Table 4). Application with the $10 \mu \mathrm{M}$ PA inhibitor resulted in an improvement in Put, Spd, Spm and total PA contents in coleoptiles of both inbred lines, except for Put in Huang C, which was found to be higher in the plants treated with $100 \mu \mathrm{M}$ of PA inhibitors as compared with other PA inhibitors. It can be concluded that 10 , 100, 500 and $1000 \mu \mathrm{M}$ of PA inhibitors resulted in the following: the reduction of Put in the coleoptiles by $68.41 \%, 68.72 \%, 73.09 \%$ and $73.92 \%$, respectively; the reduction of Spd by $21.76 \%, 63.20 \%, 48.22 \%$ and $57.61 \%$, respectively; and the reduction of Spm by $57.88 \%$, $85.18 \%, 62.95 \%$ and $85.65 \%$, respectively, relative to their controls (Table 4 ).

Table 4. Effect of polyamine inhibitor combination treatments on polyamine concentrations of coleoptile ( $\mathrm{n} \mathrm{mol} / \mathrm{g}$ FW) under low-temperature stress.

\begin{tabular}{|c|c|c|c|c|c|c|c|c|}
\hline \multirow{2}{*}{ Treatment } & \multicolumn{2}{|c|}{ Put } & \multicolumn{2}{|c|}{ Spd } & \multicolumn{2}{|c|}{ Spm } & \multicolumn{2}{|c|}{ Total Polyamines } \\
\hline & Mo17 & Huang C & Mo17 & Huang C & Mo17 & Huang C & Mo17 & Huang C \\
\hline 0 (CK) & $2044.7 \mathrm{a}$ & $932.9 \mathrm{a}$ & $535.3 \mathrm{a}$ & $619.9 \mathrm{a}$ & $80.5 \mathrm{a}$ & $81.2 \mathrm{a}$ & $2660.5 \mathrm{a}$ & $1634.0 \mathrm{a}$ \\
\hline $10 \mu \mathrm{M}$ Сo. & $620.5 c$ & 319.7 c & $439.4 \mathrm{~b}$ & $464.4 \mathrm{~b}$ & $51.4 \mathrm{~b}$ & $16.7 \mathrm{c}$ & $1111.3 \mathrm{~b}$ & $800.6 \mathrm{~b}$ \\
\hline 100 нM Co. & $604.3 c$ & $326.4 \mathrm{c}$ & $338.4 \mathrm{c} \mathrm{d}$ & $390.8 c$ & $43.4 \mathrm{c}$ & $12.9 \mathrm{~d}$ & $986.1 \mathrm{c}$ & $730.1 \mathrm{c}$ \\
\hline 500 нM Co. & $556.2 \mathrm{~d}$ & $244.6 \mathrm{~d}$ & $363.5 c$ & $235.2 \mathrm{f}$ & $46.3 c$ & $13.6 \mathrm{~d}$ & $965.9 c$ & $493.3 \mathrm{~d}$ \\
\hline $1000 \mu \mathrm{M}$ Co. & $529.0 \mathrm{e}$ & $247.0 \mathrm{~d}$ & $231.6 \mathrm{e}$ & $258.0 \mathrm{e}$ & $13.9 \mathrm{e}$ & $9.3 \mathrm{e}$ & $744.4 \mathrm{~d}$ & $514.3 \mathrm{~d}$ \\
\hline Spd + 1 mM Co. & $778.4 \mathrm{~b}$ & $369.0 \mathrm{~b}$ & $315.0 \mathrm{~d}$ & $314.2 \mathrm{~d}$ & $31.7 \mathrm{~d}$ & $32.7 \mathrm{~b}$ & $1125.0 \mathrm{~b}$ & $715.8 \mathrm{c}$ \\
\hline
\end{tabular}

Different letters following the data within each column mean significant difference at $p \leq 0.05$.

\subsection{Polyamine Biosynthetic and Degradative Enzymes under Chilling Stress}

The enzymes involved in PA synthesis (ODC and SAMDC) and polyamines' degradation $(\mathrm{PAO})$ as affected by the PA inhibitors and chilling stress are illustrated in Figure 1. The highest activity of ODC was observed under control condition as compared with $1000 \mu \mathrm{M}$ Co. (Figure 1). The activity of ODC was significantly decreased by $1000 \mu \mathrm{M} \mathrm{Co}$. in both maize inbred lines as compared with the control condition (Figure 1A-C). The combination of Spd with $1000 \mu \mathrm{M}$ Co. noticeably affected the ODC activity in roots and coleoptiles (Figure 1A,B), while there were no significant effects observed in mesocotyls in the Huang $C$ inbred line (Figure 1C). The activity of SAMDC was significantly decreased in roots, coleoptiles and mesocotyls at the exposure of $1000 \mu \mathrm{M} \mathrm{Co}$. as compared to controls and 
Spd $+1000 \mu \mathrm{M}$ Co. treatments (Figure 1D-F). There was no significant difference between controls and Spd $+1000 \mu \mathrm{M}$ Co. treatments except in the coleoptiles of Hang C inbred line that showed significant differences. The incorporation of Spd with $1000 \mu \mathrm{M} \mathrm{Co}$. PA inhibitors significantly improved the activity of SAMDC in roots, coleoptiles and mesocotyls in both maize inbred lines (Figure 1D-F). The activity of PAO was greatly increased in roots, coleoptiles and mesocotyls of both maize inbred lines when $1000 \mu \mathrm{M} \mathrm{Co}$. was applied under chilling stress (Figure 1G-I). However, there was a significant decrease in PAO activity on plants that were treated with the combined of Spd and $1000 \mu \mathrm{M}$ PA inhibitor combinations.

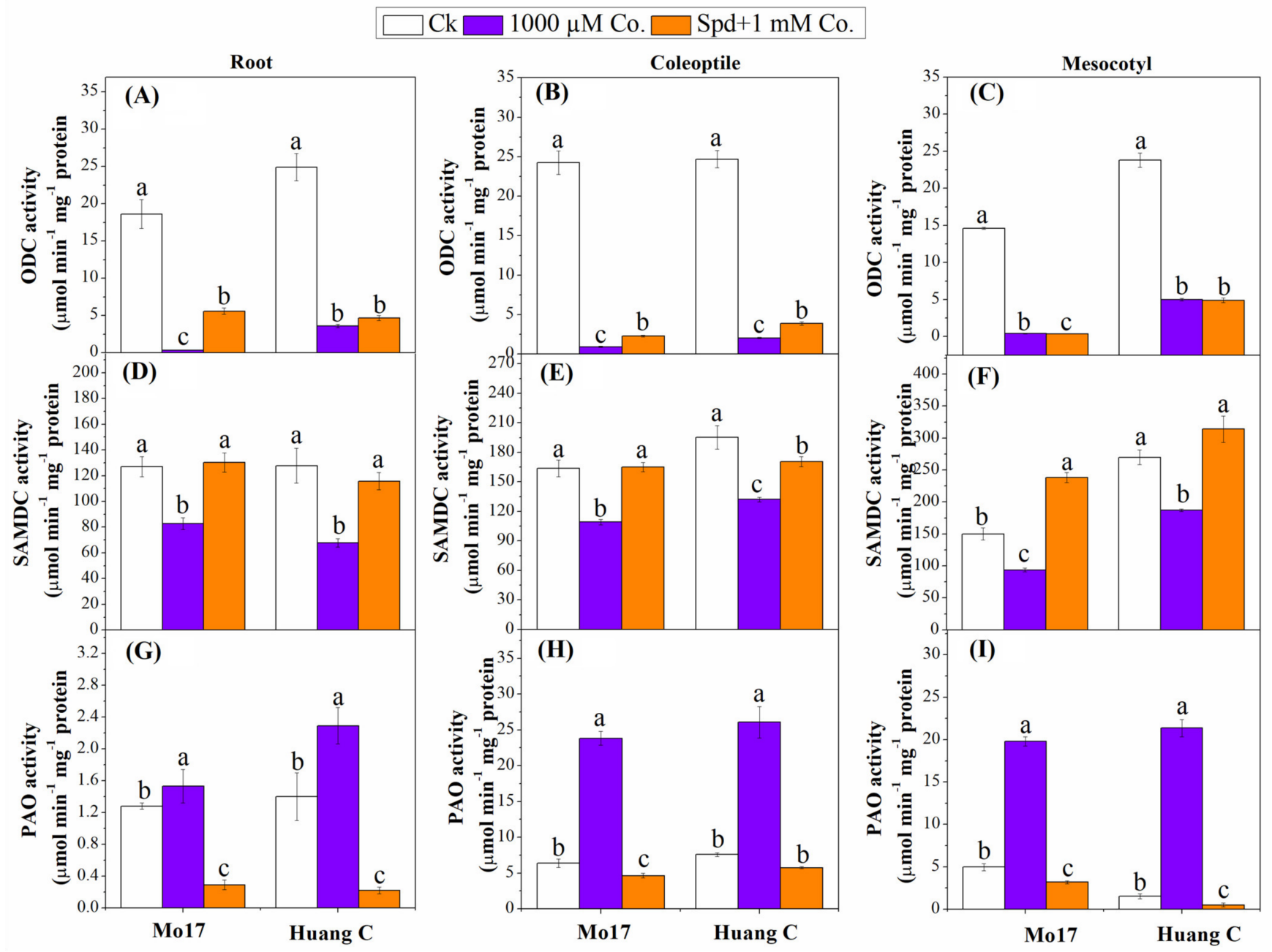

Figure 1. Effects of polyamine inhibitor combinations on ODC activity (A-C), SAMDC activity (D-F) and PAO activity (G-I) in the root, coleoptiles and mesocotyls of two maize inbred lines under chilling stress. Different letters mean significant difference at $p \leq 0.05$.

\subsection{Polyamines Biosynthesis Genes in Response to PA Inhibitors under Chilling Stress}

In order to reveal the molecular mechanisms by which PAs could help maize plans to cope with chilling stress, the PA biosynthesis genes were determined. The results from Figure 2 indicated the relative expression of $A D C 1, A D C 2$ and $O D C$ genes in different tissues of both maize inbred lines under PA inhibitors and chilling stress. The expression level of $A D C 1$ gene was significantly downregulated in roots and mesocotyls of both inbred lines when $1000 \mu \mathrm{M}$ Co. and Spd $+1000 \mu \mathrm{M}$ Co. were applied (Figure 2A-C). Interestingly, the expression of $A D C 1$ gene was upregulated in the coleoptile of both inbred lined under the same conditions (Figure 2B). The expression level of $A D C 1$ was found to be higher in the roots and mesocotyls of Mo17 inbred line when treated with 
$1000 \mu \mathrm{M}$ Co PA inhibitors as compared with Spd $+1000 \mu \mathrm{M}$ Co. treatment. A similar trend was observed in case of $A D C 2$ expression in both inbred lines under the same conditions (Figure 2D-F). The expression level of $A D C 2$ was significantly upregulated in the roots of Mo17 inbred line and in the mesocotyls of Huang $C$ inbred upon being treated with $1000 \mu \mathrm{M}$ Co PA inhibitors as compared to being treated with Spd $+1000 \mu \mathrm{M}$ Co. treatment. The relative expression of $O D C$ in the roots and mesocotyls was found to be higher in control seedlings and significantly downregulated under $1000 \mu \mathrm{M} \mathrm{Co}$. and Spd $+1000 \mu \mathrm{M}$ Co treatments (Figure 2G-I). On the other hand, ODC displayed a significant upregulation in the coleoptiles of both inbred lines against $1000 \mu \mathrm{M}$ Co. and Spd $+1000 \mu \mathrm{M}$ Co. treatments (Figure $2 \mathrm{H}$ ).

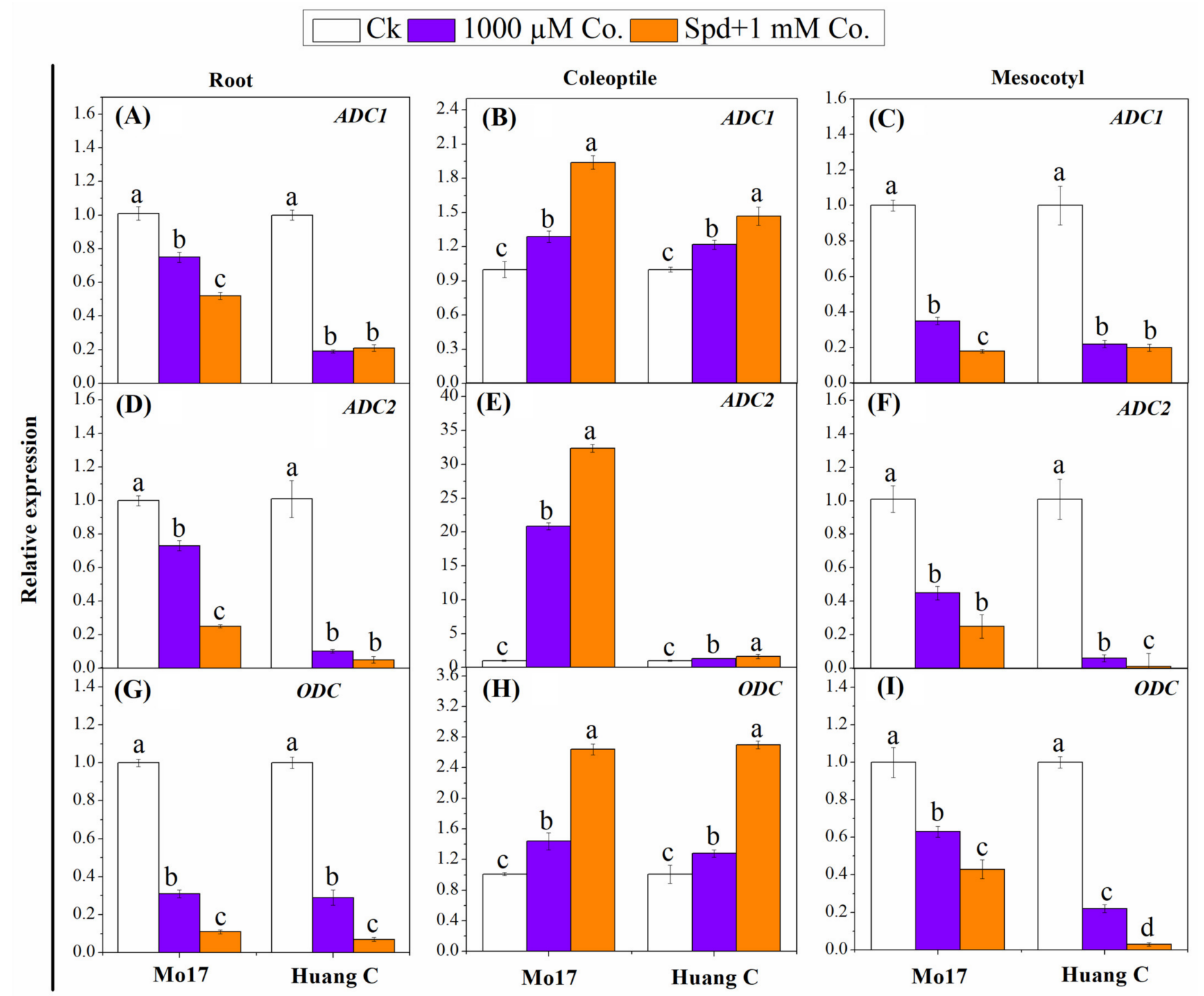

Figure 2. Effects of polyamine inhibitors combination on the relative expression of $A D C 1(\mathbf{A}-\mathbf{C}), A D C 2$ (D-F) and $O D C$ (G-I) in the root, coleoptiles and mesocotyls of two maize inbred lines under chilling stress. Different letters mean significant difference at $p \leq 0.05$.

The relative expression level of $S A M D C 2$ genes in studied plant tissues of both inbred lines were significantly downregulated when $1000 \mu \mathrm{M}$ Co. was applied under chilling stress (Figure $3 \mathrm{~A}-\mathrm{C}$ ). The expression levels of $S A M D C 2$ were higher in both maize inbred lines treated with Spd $+1000 \mu \mathrm{M}$ Co. as compared with plants treated with the $1000 \mu \mathrm{M}$ PA inhibitor alone. Higher expression levels of $S A M D C 2$ genes in maize tissues were observed under the control conditions. In contrast, the relative expression levels of SPDS were 
significantly upregulated in the seeds treated with both $1000 \mu \mathrm{M}$ Co. and Spd $+1000 \mu \mathrm{M}$ Co., especially in the Mo17 inbred line (Figure 3D-F). The highest expression level of SPDS in all maize tissues was observed with Spd $+1000 \mu \mathrm{M}$ Co. treatment of the Mo17 inbred line. Interestingly, similar treatment resulted in the lowest expression level of SPDS in the tissues of the Huang C inbred line (Figure 3D-F). Application of the $1000 \mu \mathrm{M}$ PA inhibitor alone recorded a higher expression level of SPDS in roots, coleoptiles and mesocotyls of the Huang C inbred line as compared with Spd + $1000 \mu \mathrm{M}$ Co. treatment.
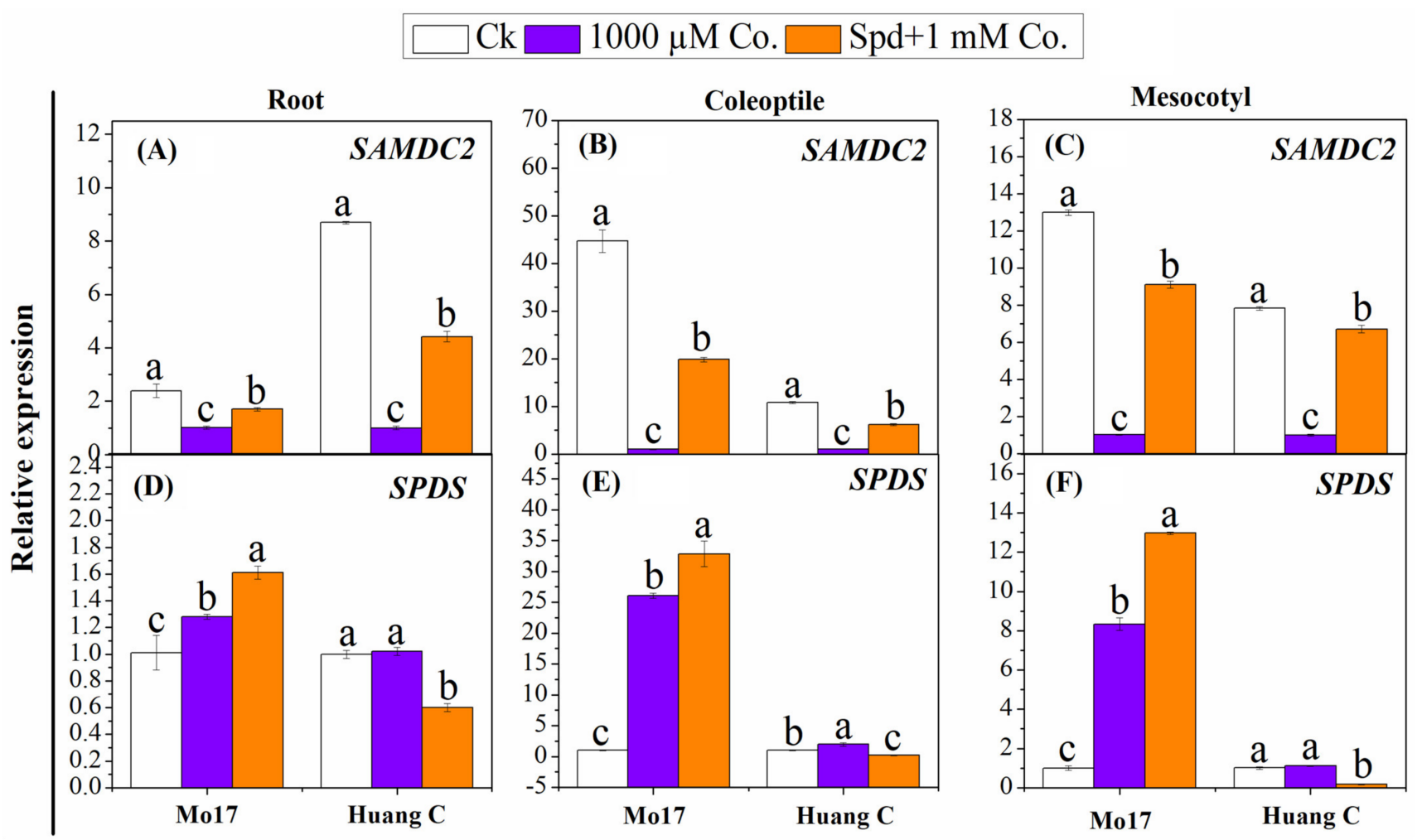

Figure 3. Effects of polyamine inhibitors combination on the relative expression of SAMDC2 (A-C) and SPDS (D-F) in the root, coleoptiles and mesocotyls of two maize inbred lines under chilling stress. Different letters mean significant difference at $p \leq 0.05$.

Mean data regarding the relative expression of the enzyme involved in the PAs degradative enzymes are presented in Figure 4. The relative expressions of PAO1, PAO2 and $P A O 3$ genes in the targeted tissues of both maize inbred lines were significantly upregulated in the seedlings that were treated with $1000 \mu \mathrm{M} \mathrm{Co}$. as compared to the relative controls (Figure 4). Combining Spd with $1000 \mu \mathrm{M} \mathrm{Co}$. resulted in the downregulation of these genes under chilling stress. The lowest expression levels of $P A O 1, P A O 2$ and $P A O 3$ were observed with Spd $+1000 \mu \mathrm{M}$ Co. in the root of Mo17, while the lowest expression levels of these genes were noticed in the coleoptiles and mesocotyls of Mo17 inbred line (Figure 4). 


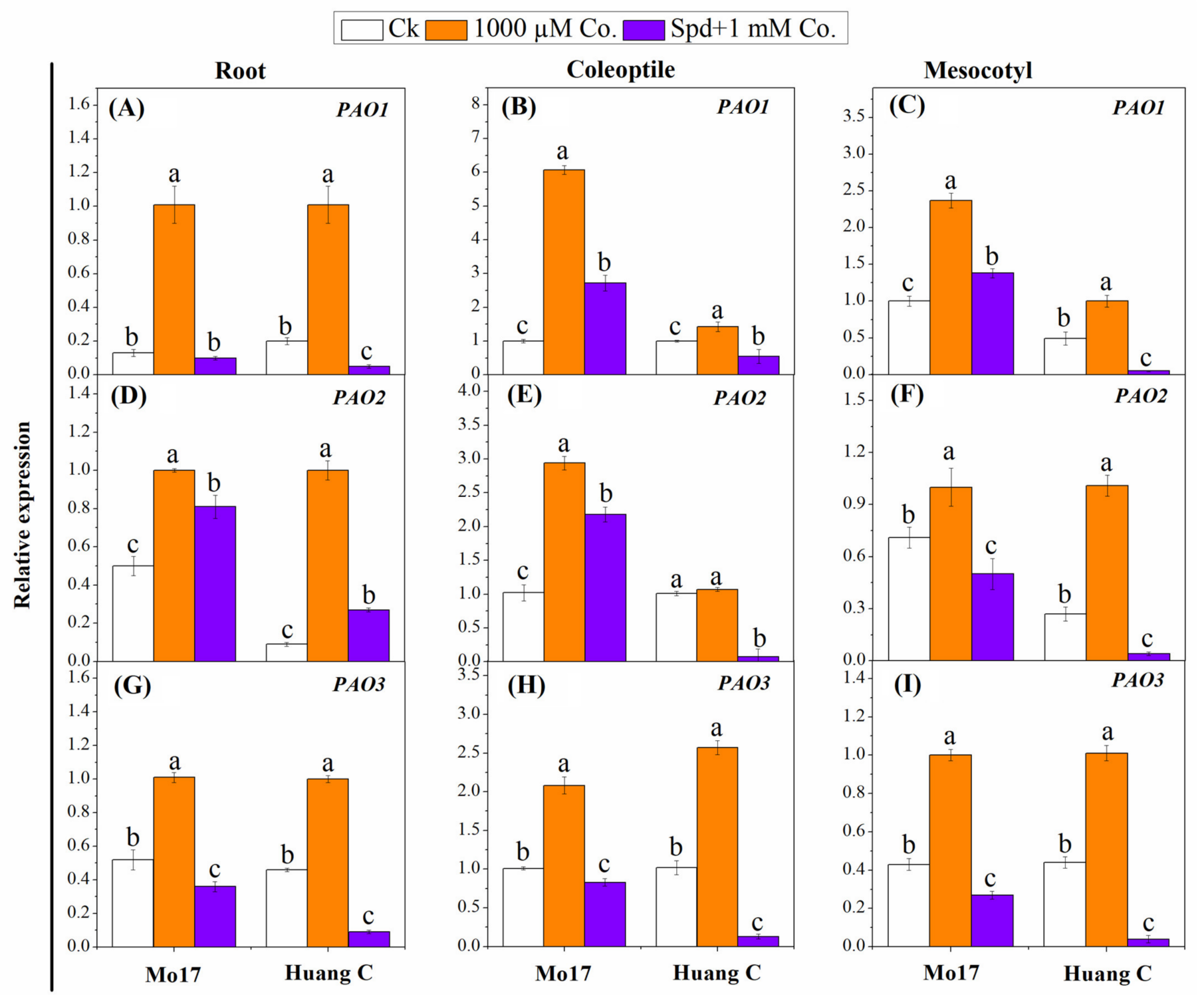

Figure 4. Effects of polyamine inhibitors combinations on the relative expression of PAO1 (A-C), PAO2 (D-F) and PAO3 (G-I) in the root, coleoptiles and mesocotyls of two maize inbred lines under chilling stress. Different letters mean significant difference at $p \leq 0.05$.

\section{Discussion}

Abiotic stresses specifically chilling stress have severely affected the plant growth and development globally $[65,66]$. Generally, plants with high-stress tolerance have differentially enhance PA biosynthesis in response to chilling stress [67]. PAs play crucial roles for in abiotic stress adaptation, which might be due to their roles in osmotic regulation, inhibition in lipid peroxidation and scavenging oxidative stress by improving antioxidant enzymes and inducing hormones and ethylene signaling [68]. Moreover, the inhibitor combination treatments could also regulate the interaction between the different PA compositions under chilling stress, leading to enhancement in seedlings' growth and development [69]. In the present study, the chilling sensitive Mo17 did not recover after the recovery period under normal temperature in the seedlings treated with the $1000 \mu \mathrm{M}$ combination inhibitor. However, the cold-tolerant Huang $\mathrm{C}$ showed a reverse trend under the same conditions and inhibited the growth reduction. However, the growth of Mo17 was found to be recovered upon being treated with the $\mathrm{Spd}+1 \mathrm{mM}$ combination, while it was not effective for the recovery of Huang C. It could be stated that Spd had better growth 
recovering effects on maize chilling-sensitive inbred lines than cold-tolerant inbred lines under low chilling stress.

PAs are endogenous plant growth regulators that can stimulate plant growth and development under different abiotic stresses [70-72]. Several studies have reported that PAs contributed to the regulation of plants' responses to various environmental constrains through binding the membrane phospholipids, scavenging free radicals by increasing the antioxidant enzymes' activities and osmotic adjustment [73,74]. In the present study, two maize inbred lines were treated with four types of PA inhibitors under chilling stress. The concentrations of Put, Spd, Spm and the total PAs in different tissues of maize seedling were obviously declined under PA inhibitor treatments. These findings stated that the PA inhibitors can be accumulated causing inhibition in the synthesis of PAs. Moreover, there was no significant difference in Put concentration between $500 \mu \mathrm{M}$ and $1000 \mu \mathrm{M}$ combination treatments in all tissues of both inbred lines, except in the coleoptiles of Mo17. Both Mo17 and Huang C inbred lines showed different patterns in the accumulation of PAs under both chilling stress and the PA inhibitor treatments. As such, the authors of [75] reported that differences in genotypes to stress have displayed diverse degrees of PAs' accumulation under abiotic stresses. Strikingly, previous reports stated that higher contents of Spd and Spm were synthesized by tolerant species, while a higher concentration of Put was synthesized by the sensitive species of the same plant variety under the same stress conditions [76-78]. In the present study, Put concentrations in the tissues of both inbred lines' seedlings treated with the Spd $+1 \mathrm{mM}$ combination were significantly higher than those in the seedlings treated with the $1000 \mu \mathrm{M}$ combination treatments, suggesting that Spd can be converted to Put and thus enhance chilling stress tolerance. Moreover, the results the conversion efficiency of Spd to Put in the root were found to be higher than those found in mesocotyls and coleoptiles. Probably, PAs carried out more transport distance to the roots than shoots. The present study is consistent with the previous study by Moschou et al. [79] in tobacco (Nicotiana tabacum), indicating that the Spd and Spm synthesis was higher in the shoot, while Put synthesis was more in roots. This demonstrates the significant increase in root viability, length and root mortality during germination in the seeds primed with exogenous Spd under water stress [80]. A similar study also by $\mathrm{Xu}$ et al. [81] reported that Put treatment was more effective for tobacco roots than shoots during seed germination under chilling stress. A recent study showed that Spd stimulated the phytohormones' metabolisms, such as GA and ethylene, and simultaneously inhibited ABA biosynthesis, leading to improved seed germination and vigor of maize seeds [36]. In the present study, Put, Spd, Spm and total polyamine contents in the different maize tissues were significantly improved by the application with Spd and $1000 \mu \mathrm{M}$ Co. of PA inhibitors as compared with the PA inhibitors alone. This might be due to the capability of Spd treatment to improve Spd uptake and SAMDC activity and to simultaneously reduce PAO activity, and consequently, reduce the PA biosynthesis-related enzymes [82]. Interestingly, the application with Spd along with PA inhibitor combinations showed different patterns for the PA enzymes' activities and their transcript levels in the different maize tissues; this might be reflecting a different feedback regulation of Spd under chilling stress. The present study showed that the PA inhibitors cause a significant reduction in the PA contents, PA biosynthesis-related enzymes and their transcript levels; this might be due to increasing of the cell membrane integrity with the application of PA inhibitors [36]. However, the application of the PAs diminished the detrimental effects of PA inhibitors through alleviation the oxidative damage in the plants by scavenging the free radicals [39].

Put and Spd concentrations were highly increased upon being treated with the Spd and $1 \mathrm{mM}$ combination as compared with those treated with the $1000 \mu \mathrm{M}$ combination. This statement supports the potential resources for the conversion of Spd to Put and can be used a physiological signal in maize under chilling stress. These results are consistent with the previous study, reporting that the conversion efficiency of Spd to Put might be related with the absorption and transportation of Spd in seedlings tissues [83]. The present study stated that the differences in the absorption and transform of Spd may vary according to 
the genotype tolerance to chilling stress, and it seemed that a higher Spd concentration was absorbed and, simultaneously, a higher Put concentration was produced from Spd to improve the cold resistance in chilling-sensitive Mo17. These findings are consistent with the results under normal temperature conditions [84]. However, De-Agazio et al. [85] suggested that Spd from did not convert to Put regardless of the plant growth condition. However, the chemical and physiological processes underlying the Spd conversation to Put in more plants need to be further studied.

In the present study, Spd treatments inhibited the PA inhibitors' effects and simultaneously improved the PA biosynthesis-related enzymes such as ADC, ODC, SAMDC and Spd synthase under chilling stress conditions. These enzymes have differential responses to the different stresses; as such, ADC is more specifically responsive to environmental stress, while ODC is more responsive to any kind of stress [30,39]. Similarly, ADC contributed to increased Put concentrations under abiotic stress [86]. In the present study, an increase in PAO activity, an enzyme involved in the PAs' degradation, was observed in the plants treated with the PA inhibitors under chilling stress, which was diminished by Spd applications. These results are in line with the findings of Amini et al. [28], who observed an increase in PAO activity under cold stress, which might be due to the reduction in Put and Spd levels. Our previous study also reported that the increase in SAMDC activity resulted in escalated uptake of Spd, and thus enhanced the chilling tolerance of rice cultivars [39].

In order to investigate the molecular mechanisms of PA biosynthesis in response to chilling stress further, the transcript levels of their genes were analyzed in the present study. The genetic manipulation of crop plants with genes encoding enzymes of PA biosynthetic pathways may provide better stress tolerance to crop plants [86]. These genes have been investigated under different environmental stresses and at different growth stages of several plant species $[49,52,53]$. In the present study, the Spd-treated seedling resulted in the upregulation of $A D C 1, A D C 2, O D C$ and $S A M D C 2$ transcripts and SPDS, and decreased the relative expression of $P A O 1, P A O 2$ and $P A O 3$ genes, irrespective of the chilling stress and PA inhibitors. These genes were also upregulated in rice seedlings exposed to chilling stress [39]. Previously, the expression levels of $A D C 2$ gene were downregulated by the induction of $O D C 1$ gene under salinity stress, suggesting that the involvement of $A D C$ pathway for the PA biosynthesis in higher plants under abiotic stresses [87]. Similarly, a significant increase in transcript levels of $A D C$, SPDS1, SPDS2 and SPMS genes was observed in the chilling-tolerant and chilling-sensitive genotypes, respectively, whereas the expression of $O D C$ genes decreased significantly in all genotypes under chilling stress [28]. Another study has reported that the relative expressions of $A D C 2$ genes were upregulated in Arabidopsis thaliana and rice [47,88]. Moreover, overexpression of the Spd synthase gene in transgenic Arabidopsis thaliana maintained higher levels of Spd contents and enhanced the plant tolerance to chilling, suggesting that Spd plays an important role as an osmolyte regulator in stress signaling pathways, which boosts stress tolerance mechanisms in plants under stress conditions [35]. The decrease of PAs might be due to the increasing conversion rate of SAM to dcSAM by increasing the transcript levels of $S A M D C 2$, leading to efficient conversion that resulted in the reduction of Put and Spd levels [89]. These PAO genes have been investigated in different plant species such as $A$. Thaliana [90], tobacco [91], rice [92], barley [93] and maize [94].

\section{Conclusions}

In conclusion, chilling stress can reduce the polyamine (PA) contents through decreasing the activities of enzymes taking part in PA biosynthesis and increasing the degradation of the PAs through the PAO enzyme in both maize inbred lines. The application of all studied PA inhibitor combinations resulted in the reduction of PA biosynthesis and increase of polyamines' degradation. The PA inhibitors in combination with Spd treatments enhanced the levels of PA contents, enzymes related to PA biosynthesis and their relative gene expressions in roots, coleoptiles and mesocotyls under chilling stress. Both inbred lines showed different patterns to the biosynthesis and degradation of PAs under chilling stress 
and a supply of PA inhibitors. The enhanced seed development of both maize inbred lines under the PA inhibitors and chilling stress is closely associated with the elevated biosynthesis of Spd, Spm and Put in maize tissues. This suggested that Spd can maintain the balance between the activation and degradation processes of PA biosynthesis by controlling related enzymes' activities as well as transcription levels under chilling stress. The present study confirmed the involvement of PAs in the regulation of growth, development and chilling tolerance of maize seedlings, which may have implications for maize cultivation in low-temperature conditions, although field investigations are prerequisites to broaden laboratory findings.

Author Contributions: C.G. and M.S.S. initiated, designed, conducted and monitored the experiment. C.G., M.S.S. and C.L. performed the polyamine enzymes and gene expression experiments. M.S.S. and Y.G. analyzed the data. M.S.S. and C.G. wrote the first draft of the manuscript. M.S.S., C.G., Z.U., Y.G. and J.H. revised and edited the final version of the manuscript. All authors have read and agreed to the published version of the manuscript.

Funding: This research was supported by the National Natural Science Foundation of China (No. 31671774, 31371708, 31201279), National Key Research and Development Program of China (No.2018YFD0100900, 2018YFD0100800), Key Research and Development Project of Zhejiang Province (No. 2019C02004, 2019C02011), Dabeinong Funds for Discipline Development and Talent Training in Zhejiang University and Jiangsu Collaborative Innovation Center for Modern Crop Production, China.

Institutional Review Board Statement: Not applicable.

Informed Consent Statement: Not applicable.

Data Availability Statement: Not applicable.

Conflicts of Interest: The authors declare that they have no competing interest.

\section{References}

1. Sheteiwy, M.S.; AbdElgawad, H.; Xiong, Y.C.; Macovei, A.; Brestic, M.; Skalicky, M.; Shaghaleh, H.; Hamoud, Y.A.; El-Sawah, A.M. Inoculation with Bacillus amyloliquefaciens and mycorrhiza confers tolerance to drought stress and improve seed yield and quality of soybean plant. Physiol. Plant. 2021, 172, 2153-2169. [CrossRef] [PubMed]

2. Sheteiwy, M.S.; Shao, H.; Qi, W.; Daly, P.; Sharma, A.; Shaghaleh, H.; Hamoud, Y.A.; El-Esawi, M.A.; Pan, R.; Wan, Q.; et al. Seed priming and foliar application with jasmonic acid enhance salinity stress tolerance of soybean (Glycine max L.) seedlings. J. Sci. Food Agri. 2021, 101, 2027-2041. [CrossRef] [PubMed]

3. Ibrahim, H.M.; Ali, B.; El-Keblawy, A.; Ksiksi, T.; El-Esawi, M.A.; Jośko, I.; Ulhassan, Z.; Sheteiwy, M.S. Effect of Source-Sink Ratio Manipulation on Growth, Flowering, and Yield Potential of Soybean. Agriculture 2021, 11, 926. [CrossRef]

4. Yang, S.; Ulhassan, Z.; Shah, A.M.; Khan, A.R.; Azhar, W.; Hamid, Y.; Hussain, S.; Sheteiwy, M.S.; Salam, A.; Zhou, W. Salicylic acid underpins silicon in ameliorating chromium toxicity in rice by modulating antioxidant defense, ion homeostasis and cellular ultrastructure. Plant Physiol. Biochem. 2021, 166, 1001-1013. [CrossRef]

5. Ulhassan, Z.; Gill, R.A.; Huang, H.; Ali, S.; Mwamba, T.M.; Ali, B.; Huang, Q.; Hamid, Y.; Khan, A.R.; Wang, J.; et al. Selenium mitigates the chromium toxicity in Brassicca napus L. by ameliorating nutrients uptake, amino acids metabolism and antioxidant defense system. Plant Physiol. Biochem. 2019, 145, 142-152. [CrossRef]

6. Allen, D.J.; Ort, D.R. Impacts of chilling temperatures on photosynthesis in warm-climate plants. Trends Plant Sci. 2001, 6, 36-42. [CrossRef]

7. Hola, D.; Kocova, M.; Rothova, O.; Wilhelmova, N.; Benesova, M. Recovery of maize (Zea mays L.) inbreds and hybrids for chilling stress of various duration: Photosynthesis and antioxidant enzymes. J. Plant Physiol. 2007, 164, 868-877. [CrossRef]

8. He, F.; Shen, H.; Lin, C.; Fu, H.; Sheteiwy, M.S.; Guan, Y.; Huang, Y.; Hu, J. Transcriptome analysis of chilling-imbibed embryo revealed membrane recovery related genes in maize. Front. Plant Sci. 2017, 7, 1978. [CrossRef]

9. Farooq, M.; Aziz, T.; Basra, S.M.A.; Wahid, A.; Khaliq, A.; Cheema, M.A. Exploring the role of calcium to improve chilling tolerance in hybrid maize. J. Agron. Crop Sci. 2008, 194, 350-359. [CrossRef]

10. Guan, Y.J.; Hu, J.; Wang, X.J.; Shao, C.X. Seed priming with chitosan improves maize germination and seedling growth in relation to physiological changes under low temperature stress. J. Zhejiang Univ. Sci. B 2009, 10, 427-433. [CrossRef]

11. Imran, S.; Afzal, I.; Basra, S.M.A.; Saqib, M. Integrated seed priming with growth promoting substances enhances germination and seedling vigour of spring maize at low temperature. Int. J. Agric. Biol. 2013, 15, 1251-1257.

12. Ruelland, E.; Vaultier, M.N.; Zachowski, A.; Hurry, V. Cold signallong and cold acclimation in plants. Adv. Bot. Res. 2009, 49, 35-150.

13. Bano, S.; Aslam, M.; Saleem, M.; Basra, S.M.A.; Aziz, K. Evaluation of maize accessions under low temperature stress at early growth stages. J. Anim. Plant Sci. 2015, 25, 392-400. 
14. Sowinski, P.; Rudzinska-Langwald, A.; Adamczyk, J.; Kubica, I.; Fronk, J. Recovery of maize seedlings growth, development and photosynthetic efficiency after initial growth at low temperature. J. Plant Physiol. 2005, 162, 67-80. [CrossRef]

15. Aroca, R.; Irigoyen, J.J.; Sanchez-Diaz, M. Drought enhances maize chilling tolerance. II. Photosynthetic traits and protective mechanisms against oxidative stress. Physiol. Plant. 2003, 117, 540-549. [CrossRef]

16. Haldimann, P. How do changes in temperature during growth affect leaf pigment composition and photosynthesis in Zea mays genotypes differing in sensitivity to low temperature? J. Exp. Bot. 1999, 50, 543-550. [CrossRef]

17. Pinhero, R.G.; Rao, M.V.; Paliyath, G.; Murr, D.P.; Fletcher, R.A. Changes in activities of antioxidant enzymes and their relationship to genetic and paclobutrazol-induced chilling tolerance of maize seedlings. Plant Physiol. 1997, 114, 695-704. [CrossRef]

18. Foyer, C.H.; Vanacker, H.; Gornez, L.D.; Harbinson, J. Regulation of photosynthesis and antioxidant metabolism in maize leaves at optimal and chilling temperatures: Review. Plant Physiol. Biochem. 2002, 40, 659-668. [CrossRef]

19. Skrudlik, G.; Baczek-Kwinta, R.; Koscielniak, J. The effect of short warm breaks during chilling on photosynthesis and the activity of antioxidant enzymes in plants sensitive to chilling. J. Agron. Crop. Sci. 2000, 184, 233-240. [CrossRef]

20. Nayyar, H.; Chander, S. Protective effects of polyamines against oxidative stress induced by water and cold stress in chickpea. $J$. Agron. Crop. Sci. 2004, 190, 355-365. [CrossRef]

21. Sanchez, D.H.; Cuevas, J.C.; Chiesa, M.A.; Ruiz, O.A. Free spermidine and spermine content in Lotus glaber under long-term salt stress. Plant Sci. 2005, 168, 541-546. [CrossRef]

22. Takahashi, T.; Kakehi, J.I. Polyamines: Ubiquitous polycations with unique roles in growth and stress responses. Ann. Bot. 2010, 105, 1-6. [CrossRef] [PubMed]

23. Tabor, C.W.; Tabor, H. Polyamines. Annu. Rev. Biochem. 1984, 53, 749-790. [CrossRef] [PubMed]

24. Igarashi, K.; Kashiwagi, K. Polyamines: Mysterious modulators of cellular functions. Bioch. Biophys. Res. Commun. 2000, 271, 559-564. [CrossRef] [PubMed]

25. An, Z.; Jing, W.; Liu, Y.; Zhang, W. Hydrogen peroxide generated by copper amine oxidase is involved in abscisic acid-induced stomatal closure in Vicia faba. J. Exp. Bot. 2008, 59, 815-825. [CrossRef] [PubMed]

26. Schuber, F. Influence of polyamines on membrane functions. Biochem. J. 1989, 260, 1-10. [CrossRef]

27. Roychoudhury, A.; Basu, S.; Sengupta, D.N. Amelioration of salinity stress by exogenously applied spermidine or spermine in three varieties of indica rice differing in their level of salt tolerance. J. Plant Physiol. 2011, 168, 317-328. [CrossRef]

28. Amini, S.; Maali-Amiri, R.; Kazemi-Shahandashti, S.; Miguel, L.; Sadeghzadeh, B.; Sobhani-Najafabadi, A.; Kariman, K. Effect of cold stress on polyamine metabolism and antioxidant responses in chickpea. J. Plant Physiol. 2021, 258-259, 153387. [CrossRef]

29. Bouchereau, A.; Aziz, A.; Larher, F.; Martin-Tanguy, J. Polyamines and environmental challenges: Recent development. Plant Sci. 1999, 140, 103-125. [CrossRef]

30. Besford, R.T.; Richardson, C.M.; Campos, J.L.; Tiburcio, A.F. Effect of polyamines on stabilization of molecular complexes in thylakoid membranes of osmotically stressed oat leaves. Planta 1993, 189, 201-206. [CrossRef]

31. Kalia, V.C.; Gong, C.; Patel, S.K.S.; Lee, J.-K. Regulation of Plant Mineral Nutrition by Signal Molecules. Microorganisms 2021, 9 , 774. [CrossRef] [PubMed]

32. Shu, S.; Guo, S.R.; Sun, J.; Yuan, L.Y. Effects of salt stress on the structure and function of the photosynthetic apparatus in Cucumis sativus and its protection by exogenous putrescine. Physiol. Plant. 2012, 146, 285-296. [CrossRef] [PubMed]

33. Mostofa, M.G.; Yoshida, N.; Fujita, M. Spermidine pretreatment enhances heat tolerance in rice seedlings through modulating antioxidative and glycoxalase system. Plant Growth Regul. 2014, 73, 31-44. [CrossRef]

34. Yamamoto, A.; Shim, I.S.; Fujihara, S. Chilling-stress responses by rice seedlings grown with different ammonium concentration and its relationship to leaf spermidine content. J. Plant Biol. 2012, 55, 191-197. [CrossRef]

35. Kasukabe, Y.; He, L.; Nada, K.; Misawa, S.; Iharu, I.; Tachibana, S. Overexpression of spermidine synthase enhances tolerance to multiple environmental stress and up-regulates the expression of various stress-regulated genes in transgenic Arabidopsis thaliana. Plant Cell Physiol. 2004, 45, 712-722. [CrossRef]

36. Huang, Y.; Lin, C.; He, F.; Li, Z.; Guan, Y.; Hu, Q.; Hu, J. Exogenous spermidine improves seed germination of sweet corn via involvement in phytohormone interactions, $\mathrm{H}_{2} \mathrm{O}_{2}$ and relevant gene expression. BMC Plant Biol. 2017, 17, 1. [CrossRef]

37. Du, H.Y.; Wang, J.; Liu, H.P.; Yang, Q.H. Effects of seed soaking with spermidine on the germination of maize seeds. J. Anhui Agric. Sci. 2007, 35, 11009-11010.

38. Xin, S.Q.; Gao, Y.; Zhao, J.M.; Liu, X.M. Effect of seed soaking in spermidine (Spd) under salt stress on rice seed germination. North Rice 2010, 40, 23-25.

39. Sheteiwy, M.S.; Shen, H.; Xu, J.; Guan, Y.; Song, W.; Hu, J. Seed polyamines metabolism induced by seed priming with Spermidine and 5-aminolevulinic acid for chilling tolerance improvement in rice (Oryza sativa L.) seedlings. Environ. Exp. Bot. 2017, 137, 58-72. [CrossRef]

40. Galston, A.W.; Sawhney, R.K. Polyamines in plant physiology. Plant Physiol. 1990, 94, 406-410. [CrossRef]

41. Bezold, T.N.; Loy, J.B.; Minocha, S.C. Changes in the cellular content of polyamines in different tissues of seed and fruit of a normal and a hull-less seed variety of pumpkin during development. Plant Sci. 2003, 164, 743-752. [CrossRef]

42. Velikova, V.; Yordanov, I.; Edreva, A. Oxidative stress and some antioxidant systems in acid rain-treated bean plants: Protective role of exogenous polyamines. Plant Sci. 2000, 151, 59-66. [CrossRef]

43. Belle, N.A.; Dalmolin, G.D.; Fonini, G.; Rubin, M.A.; Rocha, J.B. Polyamines reduces lipid peroxidation induced by different pro-oxidant agents. Brain Res. 2004, 2, 245-251. [CrossRef] [PubMed] 
44. Moschou, P.N.; Wu, J.; Cona, A.; Tavladoraki, P.; Angelini, R.; Roubelakis, K.A. The polyamines and their catabolic products are significant players in the turnover of nitrogenous molecules in plants. J. Exp. Bot. 2012, 63, 5003-5015. [CrossRef]

45. Arun, M.; Chinnathambi, A.; Subramanyam, K.; Karthik, S.; Sivanandhan, G.; Theboral, J.; Alharbi, S.A.; Kim, C.K.; Ganapathi, A. Involvement of exogenous polyamines enhances regeneration and Agrobacterium-mediated genetic transformation in half-seeds of soybean. 3 Biotech 2016, 6, 148. [CrossRef]

46. Chattopadhyay, M.K.; Gupta, S.; Sengupta, D.N.; Ghosh, B. Expression of arginine decarboxylase in seedlings of indica rice (Oryza sativa L.) cultivars as affected by salinity stress. Plant Mol. Biol. 1997, 34, 477-493. [CrossRef]

47. Mo, H.; Pua, E.C. Up-regulation of arginine decarboxylase gene expression and accumulation of polyamines in mustard (Brassica juncea) in response to stress. Physiol. Plant. 2002, 114, 439-449. [CrossRef]

48. Hao, Y.J.; Kitashiba, H.; Honda, C.; Nada, K.; Moriguchi, T. Expression of arginine decarboxylase and ornithine decarboxylase genes in apple cells and stressed shoots. J. Exp. Bot. 2005, 56, 1105-1115. [CrossRef]

49. Legocka, J.; Kluk, A. Effect of salt and osmotic stress on changes in polyamine content and arginine decarboxylase activity in Lupinus luteus seedlings. J. Plant Physiol. 2005, 162, 662-668. [CrossRef] [PubMed]

50. Liu, J.H.; Nada, K.; Honda, C.; Kitashiba, H.; Wen, X.P.; Pang, X.M.; Moriguchi, T. Polyamine biosynthesis of apple callus under salt stress: Importance of the arginine decarboxylase pathway in stress response. J. Exp. Bot. 2006, 57, 2589-2599. [CrossRef] [PubMed]

51. Li, Z.Y.; Chen, S.Y. Differential accumulation of the S-adenosylmethionine decarboxylase transcript in rice seedlings in response to salt and drought stresses. Theor. Appl. Genet. 2000, 100, 782-788. [CrossRef]

52. Tian, A.G.; Zhao, J.Y.; Zhang, J.S.; Gai, J.Y.; Chen, S.Y. Genomic characterization of the S-adenosylmethionine decarboxylase genes from soybean. Theor. Appl. Genet. 2004, 108, 842-850. [CrossRef]

53. Li, Z.Y.; Chen, S.Y. Isolation and characterization of a salt and drought-inducible gene for S-adenosylmethionine decarboxylase from wheat (Triticum aestivum L.). J. Plant Physiol. 2000, 156, 386-393. [CrossRef]

54. Urano, K.; Yoshiba, Y.; Nanjo, T.; Igarashi, Y.; Seki, M.; Sekiguchi, F.; Yamaguchi-Shinozaki, K.; Shinozaki, K. Characterization of Arabidopsis genes involved in biosynthesis of polyamines in abiotic stress responses and developmental stages. Plant Cell Environ. 2003, 26, 1917-1926. [CrossRef]

55. Hao, Y.J.; Zhang, Z.; Kitashiba, H.; Honda, C.; Ubi, B.; Kita, M.; Moriguchi, T. Molecular cloning and functional characterization of two apple S-adenosylmethionine decarboxylase genes and their different expression in fruit development, cell growth and stress responses. Gene 2005, 350, 41-50. [CrossRef]

56. Rodríguez-Kessler, M.; Alpuche-Solísm, A.; Ruiz, O.; Jiménez-Bremont, J. Effect of salt stress on the regulation of maize (Zea mays L.) genes involved in polyamine biosynthesis. Plant Growth Regul. 2006, 48, 175-185. [CrossRef]

57. Seiler, N. Catabolism of polyamines: Review Article. Amino Acids 2004, 26, 217-233. [CrossRef]

58. Marocco, A.; Lorenzoni, C.; Fracheboud, Y. Chilling stress in maize. Maydica 2004, 50, 571-580.

59. Wallace, H.M.; Fraser, A.V. Inhibitors of polyamine metabolism: Review article. Amino Acids 2004, 26, 353-365. [CrossRef]

60. Gao, C.H.; Hu, J.; Zhang, S.; Zheng, Y.Y.; Knapp, A. Association of polyamines in governing the chilling sensitivity of maize genotypes. Plant Growth Regul. 2009, 57, 31-38. [CrossRef]

61. Joseph, M.; Tomaso, D.; Jonathan, J.H.; Leon, V.K. Transport kinetics and metabolism of exogenously applied putrescine in roots of intact maize seedlings. Plant Physiol. 1992, 98, 611-620.

62. Lee, T.M.; Lur, H.S.; Chu, C. Role of abscisic acid in chilling tolerance of rice (Oryza sativa L.) seedlings. Modulation of free polyamine levels. Plant Sci. 1997, 126, 1-10. [CrossRef]

63. Brennan, T.; Frenkel, C. Involvement of hydrogen peroxide in the regulation of senescence in pear. Plant Physiol. 1977, 3, 411-416. [CrossRef] [PubMed]

64. Sheteiwy, M.S.; Shao, H.; Qi, W.; Hamoud, Y.A.; Shaghaleh, H.; Khan, N.U.; Yang, R.; Tang, B. GABA-alleviated oxidative injury induced by salinity, osmotic stress and their combination by regulating cellular and molecular signals in rice. Int. J. Mol. Sci. 2019, 20, 5709. [CrossRef] [PubMed]

65. Sheteiwy, M.S.; Ali, D.F.I.; Xiong, Y.C.; Brestic, M.; Skalicky, M.; Hamoud, Y.A.; Ulhassan, Z.; Shaghaleh, H.; AbdElgawad, H.; Farooq, M.; et al. Physiological and biochemical responses of soybean plants inoculated with Arbuscular mycorrhizal fungi and Bradyrhizobium under drought stress. BMC Plant Biol. 2021, 21, 195. [CrossRef] [PubMed]

66. Ning, L.H.; Du, W.K.; Song, H.N.; Shao, H.B.; Qi, W.C.; Sheteiwy, M.S.A.; Yu, D.Y. Identification of responsive miRNAs involved in combination stresses of phosphate starvation and salt stress in soybean root. Environ. Exp. Bot. 2019, 167, 103823. [CrossRef]

67. Gao, C.; Sheteiwy, M.S.; Han, J.; Dong, Z.; Pan, R.; Guan, Y.; Alhaj Hamoud, Y.; Hu, J. Polyamine biosynthetic pathways and their relation with the cold tolerance of maize (Zea mays L.) seedlings. Plant Signal. Behav. 2020, 15, 1807722. [CrossRef]

68. Pang, X.; Zang, Z.; Wen, X.; Ban, Y.; Moriguchi, T. Polyamines all-purpose players in response to environment stress in plants. Plant Stress 2007, 1, 173-188.

69. Hummel, I.; Couée, I.; El Amrani, A.; Martin-Tanguy, J.; Hennion, F. Involvement of polyamines in root development at low temperature in the subantarctic cruciferous speciecs Pringlea antiscorbutica. J. Exp. Bot. 2002, 53, 1463-1473. [CrossRef]

70. Alcazar, R.; Marco, F.; Cuevas, J.C.; Patrón, M.; Ferrando, A.; Carrasco, P.; Tiburcio, A.F.; Altabella, T. Involvement of polyamines in plant response to abiotic stress. Biotechnol. Lett. 2006, 28, 1867-1876. [CrossRef]

71. Yang, J.; Zhang, J.; Liu, K.; Wang, Z.; Liu, L. Involvement of polyamines in the drought resistance of rice. J. Exp. Bot. 2007, 58, 1545-1555. [CrossRef] 
72. Torrigiani, P.; Bressanin, D.; Ruiz, K.B.; Tadiello, A.; Trainotti, L.; Bonghi, C.; Ziosi, V.; Costa, G. Spermidine application to young developing peach fruits leads to a slowing down of ripening by impairing ripening-related ethylene and auxin metabolism and signaling. Physiol. Plant. 2012, 146, 86-98. [CrossRef]

73. Kakkar, R.K.; Sawhney, V.K. Polyamine research in plants-A changing perspective. Physiol. Plant. 2002, 116, 281-292. [CrossRef]

74. Alcazar, R.; Altabella, T.; Marco, F.; Bortolotti, C.; Reymond, M.; Koncz, C.; Carrasco, P.; Tiburcio, A. Polyamines: Molecules with regulatory functions in plant abiotic stress tolerance. Planta 2010, 231, 1237-1249. [CrossRef] [PubMed]

75. Liu, J.H.; Wang, W.; Wu, H.; Gong, X.; Moriguchi, T. Polyamines function in stress tolerance: From synthesis to regulation. Front. Plant Sci. 2015, 6, 827. [CrossRef]

76. Krishnamurthy, R.; Bhagwat, K.A. Polyamines as modulators of salt tolerance in rice cultivars. Plant Physiol. 1989, 91, 500-504. [CrossRef]

77. Santa-Cruz, A.; Perez-Alfocea, F.; Caro, M.; Acosta, M. Polyamines as short-term salt tolerance traits in tomato. Plant Sci. 1998, 138, 9-16. [CrossRef]

78. Liu, H.P.; Dong, B.H.; Zhang, Y.Y.; Liu, Z.P.; Liu, Y.L. Relationship between osmotic stress and the levels of free, conjugated, and bound polyamines in leaves of wheat seedlings. Plant Sci. 2004, 166, 1261-1267. [CrossRef]

79. Moschou, P.N.; Paschalidis, K.A.; Delis, I.D.; Andriopoulou, A.H.; Lagiotis, G.D.; Yakoumakis, D.I.; Kalliopi, A.R. Spermidine exodus and oxidation in the apoplast induced by abiotic stress is responsible for $\mathrm{H}_{2} \mathrm{O}_{2}$ signatures that direct tolerance responses in tobacco. Plant Cell 2008, 20, 1708-1724. [CrossRef]

80. Li, Z.; Peng, Y.; Zhang, X.Q.; Ma, X.; Huang, L.; Yan, Y. Exogenous spermidine improves seed germination of white clover under water stress via involvement in starch metabolism, antioxidant defenses and relevant gene expression. Molecules 2014, 19, 18003-18024. [CrossRef]

81. Xu, L.X.; Han, L.B.; Huang, B.R. Antioxidant enzyme activities and gene expression patterns in leaves of Kentucky bluegrass in response to drought and post-drought recovery. J. Am. Soc. Hortic. Sci. 2011, 136, 247-255. [CrossRef]

82. Duan, J.; Li, J.; Guo, S.; Kang, Y. Exogenous spermidine affects polyamine metabolism in salinity-stressed Cucumis sativus roots and enhances short-term salinity tolerance. J. Plant Physiol. 2008, 165, 1620-1635. [CrossRef]

83. Tassoni, A.; Buuren, M.V.; Franceschetti, M.; Fornale, S.; Bagni, N. Polyamine content and metabolism in Arabidopsis thaliana and effect of spermidine on plant development. Plant Physiol. Biochem. 2000, 38, 383-393. [CrossRef]

84. De-Agazio, M.; Zacchini, M.; Federico, R.; Grego, S. Putrescine accumulation in maize roots treated with spermidine: Evidence for spermidine to putrescine conversion. Plant Sci. 1995, 111, 181-185. [CrossRef]

85. De-Agazio, M.; Grego, S.; Zacchini, M.; De Cesare, F.; Cellai, L.; Rizea-Savu, S.; Silvestro, L. 1-N-Acetylspermidine in roots of maize seedlings. Plant Sci. 1996, 121, 143-149. [CrossRef]

86. Tiburcio, A.F.; Altabella, T.; Borrell, A.; Masgrau, C. Polyamines metabolism and its regulation. Physiol. Plant. 1997, 100, 664-674. [CrossRef]

87. Gill, S.S.; Tuteja, N. Polyamines and abiotic stress tolerance in plants. Plant Signal. Behav. 2010, 5, 26-33. [CrossRef]

88. Soyka, S.; Heyer, A.G. Arabidopsis knockout mutation of ADC2 gene reveals inducibility by osmotic stress. FEBS Lett. 1999, 458, 219-223. [CrossRef]

89. Do, P.T.; Degenkolbe, T.; Erban, A.; Heyer, A.G.; Kopka, J.; Karine, I.K.; Hincha, D.K.; Ellen, Z. Dissecting rice polyamine metabolism under controlled long-term drought stress. PLoS ONE 2013, 8, e60325.

90. Fincato, P.; Moschou, P.N.; Spedaletti, V.; Tavazza, R.; Angelini, R.; Federico, R.; Roubelakis-Angelakis, K.A.; Tavladoraki, P. Functional diversity inside the Arabidopsis polyamine oxidase gene family. J. Exp. Bot. 2011, 62, 1155-1168. [CrossRef] [PubMed]

91. Yoda, H.; Hiroi, Y.; Sano, H. Polyamine oxidase is one of the key elememts for oxidative burst to induce programmed cell death in tobacco cultured cell. Plant Physiol. 2006, 142, 193-206. [CrossRef] [PubMed]

92. Ono, Y.; Kim, D.W.; Watanable, K.; Sasaki, A.; Niitsu, M.; Berberich, T.; Tusano, T.; Takahashi, Y. Constitutively and highly expressed Oryza sativa polyamine oxidase localize in peroxisomes and catalyze polyamine back conversion. Amino Acids 2012, 42, 867-876. [CrossRef] [PubMed]

93. Cervelli, M.; Cona, A.; Angelini, R.; Polticelli, F.; Federico, R.; Mariottini, P. Barley polyamine oxidase isoform with distinct structural features and subcellular localization. Eur. J. Biochem. 2001, 268, 3816-3830. [CrossRef] [PubMed]

94. Cervelli, M.; Tavladoraki, P.; Agostino, S.D.; Angelini, R.; Federico, R.; Mariottini, P. Isolation and characterization of three polyamine oxidase genes from Zea mays. Plant Physiol. Biochem. 2000, 38, 667-677. [CrossRef] 